\title{
First insights into the transfer of marketing know-how from Western firms to enterprises in Central and Eastern Europe: A qualitative study
}

\author{
Roger Bennett ${ }^{* *}$
}

This paper reports the results of case study research into the methods employed by 12 large UK-based companies when transferring marketing know-how to Central and East European (CEE) joint venture partner firms. Propositions derived from transactions cost analysis and theories concerning the optimal means for transmitting technical information between organisations are applied to the data, and the usefulness of a number of collateral hypotheses are assessed. It is concluded that certain elements of transactions cost theory stand up well in the CEE business context, but that the practical devices adopted by Western enterprises when transferring marketing know-how to foreign CEE partners need to be improved.

Dieser Artikel faßt die Ergebnisse von Fallstudienuntersuchungen bezüglich der Methodik des Marketing-know-how-Transfers nach Mittel- und Osteuropa zusammen. Dazu wurden 12 große britische Unternehmungen und deren JointVenture-Partner in Mittel- und Osteuropa untersucht. Es wurden Ansätze auf der Basis der Transaktionskostenanalyse und Theorien zur optimalen Übertragung technischer Informationen auf die Daten angewandt und eine Reihe weiterer Hypothesen geprüft. Einige Elemente der Transaktionskostenanalyse erwiesen sich im gegebenen Kontext als sehr geeignet. Die praktische Umsetzung des Know-how-Transfers bedarf aber noch erheblicher Verbesserungen.

\footnotetext{
Manuscript received: 26.5.97, accepted: 16.6.97

** Roger Bennett, born 1948, PhD, Reader in the Department of Business Studies, London Guildhall University, UK. Major areas of research: marketing communications, international business, technology transfer, management of joint ventures.

Mail address: Department of Business Studies, London Guildhall University, 84 Moorgate, London EC2M 6SQ

Tel: (44) 01713201577

Email: rbennett@lgu.ac.uk
} 


\section{Introduction}

Although a voluminous research literature exists concerning the transfer of technical information, methods and equipment between West and East European nations (see for example Gibson et al. 1990; Kerssens-Van Drongelen et al. 1996 for details of recent articles); the same cannot be said for the transmission of the knowledge and know-how needed to market successfully the outputs created by the technologies passed among firms. This is an important matter in the context of Central and East European (CEE) business, however, in view of the large number of Western companies that have recently set up technology transfer (TT) related joint ventures (JVs) with CEE enterprises (CEC 1995) in conjunction with the inadequate marketing infrastructures and low levels of marketing skill allegedly characteristic of firms within many (if not most) CEE states (see Hooley et al. 1996). Several a priori considerations suggest that Western companies might wish to transfer marketing know-how (MKH) to CEE enterprises with which they have TT arrangements. Patent licensing, franchising, profit sharing JVs and certain other TT mechanisms typically entail the owner of the intellectual property transferred (the 'transferor' company) taking a share of the profits ensuing from the activities of the recipient organisation (the 'transferee'), e.g. through royalties on the sales of the resulting output. And even if a TT agreement provides for lump sum payments not related to sales revenues the transferee's ability to meet its financial obligations often depends in reality on the level of sales achieved, hence creating incentives for transferors to want to ensure that final outputs are marketed effectively. It follows that Western firms may wish to offer advice and assistance to their CEE partners in order to improve the latter's marketing efforts. Such help could range from the provision of ad hoc contributions to specific marketing functions though to the transferor virtually taking over the transferee's marketing department.

In 1997 the author completed a survey of 209 UK-based businesses known to have recently engaged in West-East joint venture TT arrangements (Bennett 1997), from which it emerged that $65 \%$ of respondent companies had made at least some contribution to their CEE partner's marketing of the output resulting from a transferred technology. Fifteen per cent of the 209 firms assumed total responsibility for marketing the end product; $31 \%$ described the extent of the help they provided as either 'very extensive' or 'substantial', $19 \%$ as 'moderate'. The main reasons that respondents cited for intervening in transferees' marketing activities were the need to safeguard investments already sunk in West-East collaborative arrangements, uncertainty and turbulence in local CEE markets, and (overwhelmingly) lack of confidence in the marketing competence and capabilities of the foreign partner ( $50 \%$ of respondents assessed the latter as either 'poor' or 'very poor', with just $12 \%$ regarding their partner's marketing as 'excellent'). These low opinions of CEE enterprises' marketing abilities held by respondents in the author's study matched those found by other researchers in 
the field (e.g., Roos et al. 1992; Benito and Welch 1994; Welch 1996). Such investigations generally concluded that very many CEE business practices and networks continued to rely on systems, contacts and protocols developed during the communist era and that these had proven woefully inadequate for satisfying the marketing needs of competing privatised firms. Hooley et al's (1996) survey of 2311 Hungarian, Polish and Bulgarian enterprises' approaches to marketing (including marketing strategies and how they organised their marketing activities) found, moreover, that marketing was undertaken at an extremely rudimentary level in these countries, focusing almost exclusively on the immediate short term. Barely a fifth of respondents believed that marketing played a significant role within their firms; implementation skills were limited, and there was 'poor understanding of what marketing is about' (p.80). Further problems highlighted by empirical studies into CEE marketing environments include attitudinal barriers to the adoption of marketing philosophies, lack of marketing education, the casual assignment of marketing responsibilities to nonspecialist staff, absence of market research data and facilities, widespread ignorance of the benefits of marketing orientation, confusion of 'marketing' with 'selling', scant regard for product quality, widespread ignorance of the importance of pricing policy, and poor commercial infrastructure (Ennew et al. 1993; Lascu et al. 1993; Bennett 1994; Welch 1996).

The present research sought to explore these and related matters, in depth, via an examination of the situations pertaining within specific examples of West-East technology transfers known to involve the provision by the Western partner of assistance with the marketing of the end product emerging from the arrangement. Although the assumption by one company of partial (or even full) responsibility for another firm's marketing efforts commonly occurs within domestic collaborative business arrangements (e.g. if one firm has superior distribution systems for carrying the partner's product, or through the setting up of a joint marketing subsidiary - see Anderson/ Narus 1990; Bucklin/ Sengupta 1993); little is known about the precise mechanisms whereby enterprises actually transmit marketing know-how from one organisation to another, particularly in the international context. Hence the current investigation attempted to pinpoint relevant issues and to present some initial evidence on how MKH was undertaken by companies engaged in West-East technology transfer and where the Western partner contributed to the marketing of a CEE firm's goods. The study aimed to identify the problems involved and to recommend an agenda for future research into this important but unexplored field.

\section{Theory}

Theoretical propositions from a number of areas can be drawn upon to generate relevant questions concerning $\mathrm{MKH}$ transfer and a specification of how $\mathrm{MKH}$ 
ought in principle to be transmitted. The most apposite pre-existing constructs in this regard are perhaps transactions cost analysis (TCA) and theories derived from the study of techniques for the effective transfer of technical information. According to the academic literature concerning the latter (see Kerssens-Van Drongelen et al. 1996 for a review of recent contributions) an organisation possesses a 'knowledge base' wherein knowledge is stored prior to its transformation and hence implementation via useful activities. This knowledge base comprises brainware, hardware, groupware, and documentware (Zeleny et al. 1990). Brainware consists of experience, personal skill and acquired knowledge; hardware is the processes, equipment and other touchable items that incorporate knowledge. At the next level there exists groupware, which encompasses informal procedures, rules of thumb, stories and unwritten protocols; and above this documentware made up of databases, written reports, handbooks, patents, and formally documented knowledge held within information systems. A company's knowledge base, moreover, has several layers: personal, departmental, divisional, strategic business unit, and organisational. (This creates problems for technology transfer in that, very often, a large amount of a firm's knowledge is stored in brainware, i.e. the least traceable and accessible medium and hence the most difficult to transmit and then deploy in an optimal manner.) The effective transfer of know-how involves the transformation of knowledge stored in brainware in one company (and thus only available to one or a few individuals) into forms (groupware, documentware and hardware) that can be shared by many people at the organisational level. Useful devices for transferring technical knowledge identified by the (technical) TT literature include the temporary or permanent transfer of staff (brainware) to TT recipient firms, the establishment of joint subsidiaries to bring together owners and seekers of knowledge, and the creation of formal procedures for the application of specific techniques (Jain/ Triandis 1990). Brown and Eisenhardt (1995) argued that the efficacy of communications between the partners to a TT agreement crucially determined its likelihood of success. Oral communication, they concluded, was obviously important, but not necessarily the most efficient form. Rather, the sharing of tasks led to superior information flow and hence to improved performance. This could be achieved by setting up task-fulfilling project teams, especially if the teams engaged in periodic brainstorming. Interestingly, the frequency of communication between partners was not found to facilitate information transmission. Instead the 'kinds of person' involved and the quality of their relationships were more important. Doz (1988) concluded that differences in the level at which particular issues were discussed within partners of technology alliances could create significant communication difficulties. A study completed by Moenaert et al. (1992) similarly revealed that the organisational climate within a transferee's business critically influenced how readily information was received and acted upon. Other relevant factors 
were the status of the information source and the perceived relevance, reliability and credibility of the information transmitted.

\section{Transactions cost analysis (TCA)}

This is a theory which predicts that a business will perform within the firm whichever activities it can undertake at lower cost, while relying on outsiders (agents, distributors, consultancies, etc.) for activities in which the latter have a cost advantage (Williamson, 1985). External 'transactions costs' such as the costs of searching for suitable intermediaries, monitoring the latter's performances and enforcing contractual obligations would, according to Williamson (1985) be low if the market for external services was highly competitive. This was because intense competition implied a large number of service providers from which the firm could choose (so that unsatisfactory outsiders could be replaced quickly and easily), and ensured fair prices for external services. Also the threat of replacement could compel suppliers constantly to attempt to improve their levels of service quality. A major proposition of TCA is that firms are more inclined to do things for themselves (distribution, advertising management or market research for example) whenever 'transaction specific' assets accumulate. Examples of transaction specific assets are specialised knowledge, experience, and working relationships built up over time and which are unique to marketing the product(s) in question. An independent outsider gaining such knowledge, experience, etc., is difficult to replace, even if it performs badly or otherwise abuses its position. It follows that the presence of transaction specific assets ('asset specificity', as it is known) should, ceteris paribus, create an incentive to internalise a function rather than rely on outsiders (Williamson 1985; Klein et al. 1990).

Further transactions costs were said to arise from the existence of 'uncertainty' in local markets. Uncertainty could relate either to unpredictability in the decision-making environment or to ambiguities vis à vis the monitoring of outsiders' performances and ascertaining whether they were complying with their contractual obligations. These considerations give rise to the following propositions in relation to Western companies' desires to become involved in their CEE partners' marketing efforts.

P1. Intervention will be greater the higher the degree of asset specificity in relation to the engagement of external marketing services. Arguably, substantial asset specificity (i.e. the situation prevailing when extensive training, time, nurturing of business contacts, knowledge accumulation, etc, are necessary to market the end product successfully) results in Western firms wanting to manage the marketing of the end product rather than leaving this to the foreign partner. In other words the transferor will want to exercise significant control over the transferee's marketing if it believes that the development of specialised marketing skills and relationships are necessary. Transferees might not be 
deemed capable of coping with such a situation; while the transferor may be fearful of the adverse consequences of anyone in the (foreign) local market acquiring information about the end product and how it is best sold that might eventually be used against the JV's interests.

P2. Intervention will be greater the higher the level of uncertainty. As in P1, the transferor may prefer to control foreign marketing if the environment is very uncertain (i) for fear of the transferee not possessing the marketing competence to handle volatile markets, and (ii) because it wishes to safeguard the return on its investment in the joint venture.

P3. The more competitive the local foreign market for the supply of external services the higher the probability that a Western firm will be content to leave the marketing of the end product to the CEE partner. The justification here is that a competitive local market should in principle enable the transferee to utilise reliable and efficient distributors, direct marketing firms, advertising agencies and other marketing services providers to help market its output.

\section{Further possible influences}

Empirical studies into (i) the management of marketing channels generally, and (ii) the choice of mode of entry to unfamiliar (domestic) markets (see McNaughton 1996 for details of the major investigations) suggest a number of other factors that could affect the degree of transferor intervention in West-East TT, as follows.

P4. Intervention will be greater (i) the more after-sales service is required, (ii) the more complex the end product (a simple, mundane and familiar item is easier to market than something that is specialised and complicated), (iii) the closer the transferee's end product to products already supplied by the transferor, and (iv) the greater the extent to which the Western company already possesses well-established distribution facilities in the CEE country concerned (since a new product can be inexpensively added to lines carried by an existing channel).

\section{Research questions}

Apart from assessing the applicability of the above-mentioned propositions the research sought to obtain tentative answers to various questions concerning the degrees to which $\mathrm{MKH}$ transfer methods in practice corresponded to those recommended by the academic literature on the effective transmission of technical information, as previously outlined. Additionally, respondents were questioned about how they organised MKH transfer in general terms, about the communication techniques they applied, their objectives and expectations, and the nature and quality of relationships with recipient enterprises. 


\section{Methodology}

An exploratory research design was adopted in view of the absence of prior empirical investigation in the MKH transfer field and because so little is known about the natures of relevant issues. Thus the aim of the work was to discover significant variables and key relationships among them and hence lay a groundwork for subsequent more rigorous quantitative testing of hypotheses (Kerlinger 1964; Churchill 1991). Accordingly, 12 examples of Western companies known to have recently undertaken technology transfers to CEE enterprises were studied in depth, using the key informant method (see Seidler 1974; Phillips 1981). The latter necessitated the holding of interviews with executives concerned with their companies' CEE marketing operations; a methodology known to facilitate the study of decisions within their natural context (Yin 1994) and to be especially suitable for evaluating the motives behind important decisions (Robson/ Foster 1989). A further justification for the use of a case study approach is that a major reason for the lack of previous research in this area is likely to be the sensitivity and confidential nature of the legal agreements underlying technology transfers and hence the problem of finding businesses willing to divulge their cross-border TT arrangements via responses to a mail questionnaire. Face-to-face interviews stand a better chance of eliciting relevant information in these circumstances. Firms in various industry sectors were examined in order to identify relevant factors and nascent similarities and differences across industry groupings; to assess the applicability of various propositions to a selection of diverse organisations; and to suggest explanatory variables for key decisions. The comparative case study method, moreover, creates more opportunities for the triangulation of data than does the study of an individual company (i.e., evidence can be gathered from multiple sources all pointing to the same patterns and consistencies (see Bonoma 1985; Yin 1994), thus enhancing the generalisability of findings.

\section{The sample}

In 1997 the author completed a mail survey of a sampling frame of 547 UKbased companies known to have engaged in West-East TT during the previous few years. The sampling frame consisted of (i) 126 company names kindly provided by an Anglo-Hungarian trade association which had been approached by these companies for help and advice when setting up TT-related JVs in Hungary, and (ii) 421 company names obtained from the technology transfer pages of the World Wide Web and from business directory sources. The survey covered (in outline) various features of the JVs in which the Western firms had an interest, and asked whether the latter had become involved in their CEE partners' marketing of the end products resulting from technology transfers. Two hundred and nine replies were received (37\%), of which 136 stated that they had helped their foreign partners with the marketing of end products. 
Respondent companies were spread across 12 main industry sectors, plus a 'miscellaneous' category. A stratified random sample of 26 businesses was drawn from these 136 firms (the strata being the various industry sectors), and each randomly selected company then invited to participate in the investigation. Respondents in 12 companies agreed to be interviewed. The random selection of multiple firms both within and across sectors follows the procedure suggested by Yin (1994), who argued that such a procedure is likely to yield information suggesting either (i) similar conclusions ('literal' replication), or (ii) contradictory conclusions but for predictable reasons ('theoretical' replication). Thus, the drawing of cases at random from various industry sectors ought in principle to produce (by chance) a few literal replications plus a number of theoretical replications which, if they all point in the same direction, should provide substantive support for or refutations of the initial set of propositions.

Figure 1: The interview plan

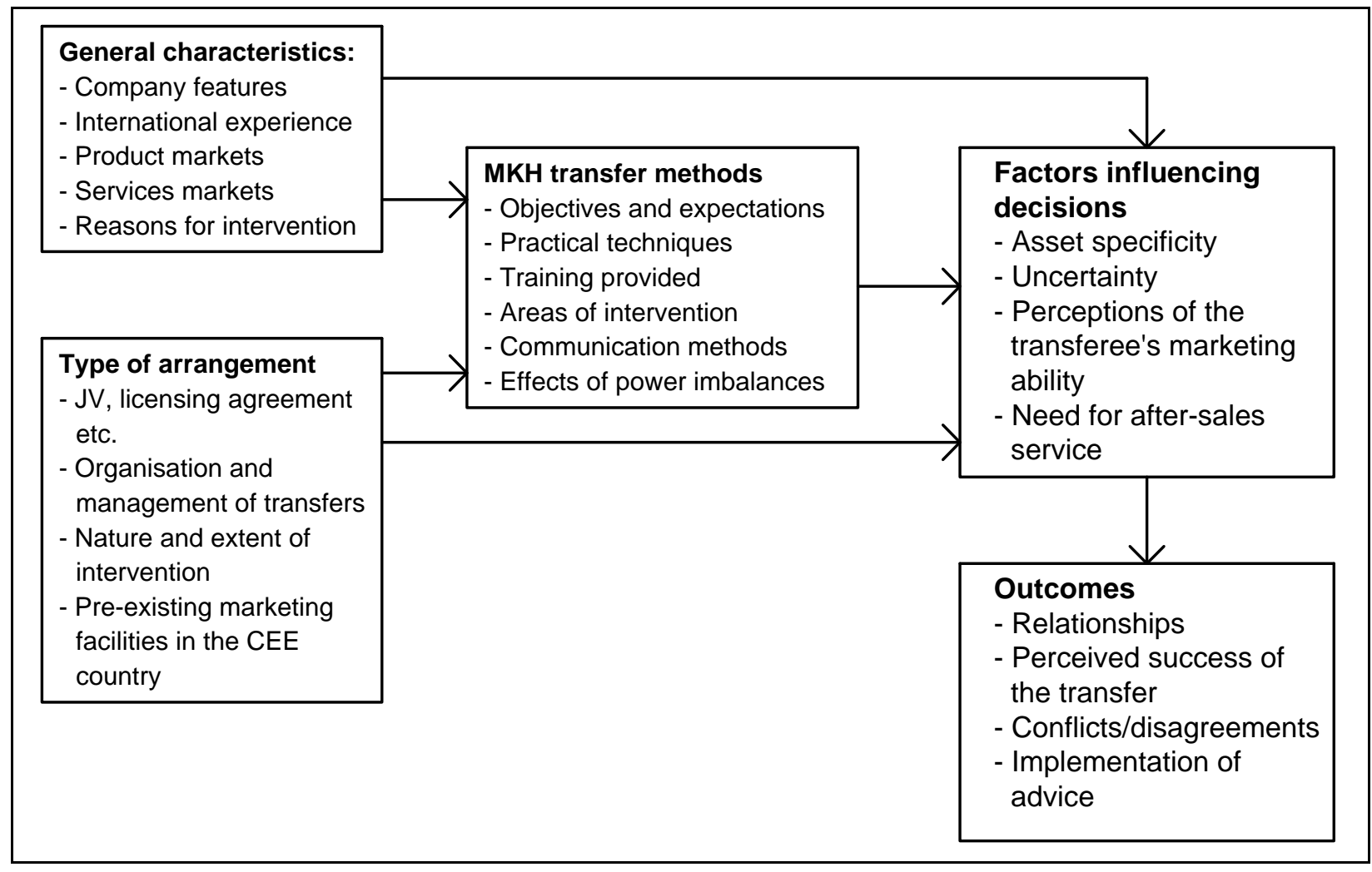


Table 1: Characteristics of respondent companies

\begin{tabular}{|c|c|c|c|c|c|c|c|c|c|c|c|c|}
\hline Company & 1 & 2 & 3 & 4 & 5 & 6 & 7 & 8 & 9 & 10 & 11 & 12 \\
\hline Employees & 21500 & 12200 & 8300 & 5400 & 7000 & 2500 & 900 & 690 & 727 & 800 & 1620 & 530 \\
\hline Annual turnover & \begin{tabular}{|l|}
3.8 \\
billion
\end{tabular} & \begin{tabular}{|l|}
2.1 \\
billion
\end{tabular} & \begin{tabular}{|l|}
$£ 1.4$ \\
billion
\end{tabular} & $\begin{array}{l}£ 780 \\
\text { million }\end{array}$ & \begin{tabular}{|l|}
$£ 470$ \\
million
\end{tabular} & $\begin{array}{l}£ 270 \\
\text { million }\end{array}$ & $\begin{array}{l}109 \\
\text { million }\end{array}$ & $\begin{array}{l}£ 83 \\
\text { million }\end{array}$ & $\begin{array}{l}£ 46 \\
\text { million }\end{array}$ & $\begin{array}{l}£ 32 \\
\text { million }\end{array}$ & $\begin{array}{l}£ 28 \\
\text { million }\end{array}$ & \begin{tabular}{|l|}
$£ 22$ \\
million
\end{tabular} \\
\hline Industry sector & $\begin{array}{l}\text { Pharma- } \\
\text { ceuticals }\end{array}$ & Chemicals & $\begin{array}{l}\text { Engineer- } \\
\text { ing }\end{array}$ & Plastics & $\begin{array}{l}\text { Clothing } \\
\text { manu- } \\
\text { facture } \\
\end{array}$ & Chemicals & $\begin{array}{l}\text { Electrical } \\
\text { equipment }\end{array}$ & Rubber & Plastics & Leather & $\begin{array}{l}\text { Agro- } \\
\text { alimen- } \\
\text { taries } \\
\end{array}$ & $\begin{array}{l}\text { Agro- } \\
\text { alimen- } \\
\text { taries }\end{array}$ \\
\hline $\begin{array}{l}\text { Locations of foreign } \\
\text { business operations }\end{array}$ & $\begin{array}{l}\text { World- } \\
\text { wide }\end{array}$ & $\begin{array}{l}\text { World- } \\
\text { wide }\end{array}$ & $\begin{array}{l}\text { World- } \\
\text { wide }\end{array}$ & $\begin{array}{l}\text { Mainly } \\
\text { Europe } \\
\text { and Asia }\end{array}$ & $\begin{array}{l}\text { World- } \\
\text { wide }\end{array}$ & $\begin{array}{l}\text { World- } \\
\text { wide }\end{array}$ & $\begin{array}{l}\text { Europe } \\
\text { and USA }\end{array}$ & $\begin{array}{l}\text { Europe } \\
\text { and USA }\end{array}$ & $\begin{array}{l}\text { World- } \\
\text { wide }\end{array}$ & $\begin{array}{l}\text { World- } \\
\text { wide }\end{array}$ & Europe & $\begin{array}{l}\text { Europe } \\
\text { and Asia }\end{array}$ \\
\hline \begin{tabular}{|l|l|} 
Extent of inter- \\
national experience
\end{tabular} & \begin{tabular}{|l|} 
More than \\
20 years
\end{tabular} & $\begin{array}{l}\text { More than } \\
20 \text { years }\end{array}$ & 15 years & 18 years & \begin{tabular}{|l|} 
More than \\
20 years
\end{tabular} & \begin{tabular}{|l|} 
More than \\
20 years
\end{tabular} & 10 years & 14 years & 15 years & \begin{tabular}{|l|} 
More than \\
20 years
\end{tabular} & 10 years & 10 years \\
\hline \begin{tabular}{|l}
$\begin{array}{l}\text { Extent of } \\
\text { experience }\end{array}$ \\
\end{tabular} & \begin{tabular}{|l|} 
More than \\
20 years
\end{tabular} & \begin{tabular}{|l|} 
More than \\
20 years
\end{tabular} & 15 years & 8 years & 10 years & 15 years & 6 years & 5 years & 6 years & 8 years & 5 years & 10 years \\
\hline $\begin{array}{l}\text { Past involvement with } \\
\text { the CEE partner }\end{array}$ & No & Yes & Yes & No & No & Yes & Yes & Yes & No & Yes & No & No \\
\hline CEE partner's location & Hungary & Bulgaria & Russia & Hungary & $\begin{array}{l}\text { Czech } \\
\text { Republic }\end{array}$ & Romania & $\begin{array}{l}\text { Czech } \\
\text { Republic }\end{array}$ & Poland & Romania & Slovakia & Hungary & Poland \\
\hline $\begin{array}{l}\text { Nature of the colla- } \\
\text { borative arrangement }\end{array}$ & $\begin{array}{l}\text { Contract } \\
\text { with } \\
\text { licensing } \\
\text { agreement }\end{array}$ & $\begin{array}{l}\text { Equity JV } \\
\text { with majo- } \\
\text { rity share- } \\
\text { holding } \\
\text { and a } \\
\text { licensing } \\
\text { agreement }\end{array}$ & $\begin{array}{l}\text { Equity JV } \\
\text { with } \\
\text { majority } \\
\text { share- } \\
\text { holding }\end{array}$ & Contract & $\begin{array}{l}\text { Contract } \\
\text { with } \\
\text { licensing } \\
\text { agreement }\end{array}$ & $\begin{array}{l}\text { Equity JV } \\
\text { with mino- } \\
\text { rity share- } \\
\text { holding } \\
\text { and a } \\
\text { licensing } \\
\text { agreement } \\
\end{array}$ & Contract & $\begin{array}{l}\text { Contract } \\
\text { with } \\
\text { licensing } \\
\text { agreement }\end{array}$ & $\begin{array}{l}\text { Contract } \\
\text { with } \\
\text { licensing } \\
\text { agreement }\end{array}$ & Contract & $\begin{array}{l}\text { Equity JV } \\
\text { with } \\
\text { minority } \\
\text { share- } \\
\text { holding }\end{array}$ & Contract \\
\hline $\begin{array}{l}\text { Did the Western firm } \\
\text { already have a branch } \\
\text { or subsidiary in the } \\
\text { transferee's country? }\end{array}$ & Yes & Yes & Yes & No & Yes & Yes & Yes & No & Yes & No & Yes & No \\
\hline $\begin{array}{l}\text { Respondent's estimate } \\
\text { of the number of } \\
\text { employees in the CEE } \\
\text { partner }\end{array}$ & 1200 & 850 & 700 & 60 & 250 & 2500 & 100 & 75 & 150 & 80 & 3000 & 200 \\
\hline
\end{tabular}


A total of 14 interviews were conducted in the 12 firms either with a person closely connected with his or her company's Central and East European marketing operations, or with other senior managers (e.g. export director, licensing manager). In 2 companies a second interview took place with a second person because the first interviewee suggested that a colleague might be able to provide additional information. This is consistent with the key informant approach as recommended by the academic literature on the subject (e.g. Trembley 1982; Miles/ Huberman 1994). These key informants were able to draw on their personal experiences and specialised knowledge in order to define the essential characteristics of the problems considered. The sample was small, but reasonable considering the preliminary nature of the investigation. A brief summary of the essential characteristics of the 12 companies is shown in Table 1.

The interview procedure applied followed that recommended by Eisenhardt (1989), i.e. a semi-structured approach based on questions of a general nature derived from a comprehensive review of academic literature in relevant areas. In line with this approach, respondents were themselves allowed to determine the emphasis given to various questions, detailing the factors they believed most relevant to their firms' intervention decisions and omitting or explaining the perceived irrelevance of other variables. Unfortunately respondents' comments could not be verified (via press coverage or market research reports for example), although there were no a priori reasons for supposing that interviewees would wish to provide misleading information. A schematic overview of the issues and linkages explored in the interviews is presented in Figure 1. This was used as a general guide for the progression of interviews, although care was taken not to presuppose that the dimensions outlined were all-embracing. Responses were coded under headings relating to the main propositions of the study. Verbatim quotes were also recorded where these were likely to enhance the quality of the outcomes to the investigation. Respondents' comments were analysed using a two-stage strategy beginning with a within-case study of the characteristics and behaviour of each company followed by a cross-case integration of information. The former generated a list of issues that respondents believed to be important; the latter an overall pattern of similarities and differences across companies.

\section{Findings}

Two of the Western companies (firms 2 and 3) were involved in JVs in which they held most of the equity; 2 in JV arrangements whereby the CEE partner had a majority shareholding (firms 6 and 11); and the remainder in agreements governed by contracts which specified the rights and duties of each party but without the formation of a subsidiary. Half the deals incorporated a formal licensing contract (firms 1, 2, 5, 6,8, 9). Two of the TTs could reasonably be 
described as turnkey arrangements (i.e., firms 4 and 11 had installed equipment and/or systems, and then trained local personnel to whom they handed over control of the installation). MKH transfer was organised in a variety of ways within respondent companies, as indicated in Figure 2 which shows also a summary of the firms' MKH transfer methods and areas of intervention. In 7 firms MKH transfer was the responsibility of either (i) and export or international division which looked after all the company's cross-border marketing activities, or (ii) a general marketing department that dealt with both domestic and foreign sales (see Figure 2.C). Four firms completed these tasks through pre-existing foreign branches or subsidiaries; one had set up a joint marketing subsidiary with the CEE partner specifically to manage the sale of the output emerging from a JV. By far the commonest method of assisting CEE firms with their marketing was through personal visits to transferees by marketing executives of the transferor company in order to help with particular marketing problems (only firms 10 and 12 did not regard this as one of their primary transfer mechanisms). The situation prevailing in firm 3 was explained as follows. 'We have a global marketing system with 2 or 3 of our senior people constantly moving around the world to pick up on problems as they arise. These guys are truly international in outlook and soon put things right. They regularly visit our contacts in East Europe to sort things out.' Otherwise, the visits were from marketing personnel in the transferor's local regional branch or subsidiary (firms 1, 5, 6, 7, 11) or from the Western firm's headquarters $(3,4,8,9,11)$.

Such visits were seen as a fast, convenient and reliable means of transmitting information. Two companies (2 and 5) had transferred marketing staff for short periods (described as 'a couple of weeks' in both cases). Interestingly this was not the case for either of the firms undertaking turnkey contracts.) The main functional areas in which respondents stated their companies helped their CEE partners with their marketing (see Figure 2.D) were pricing, (marketing planning and distribution). Two of the companies (2 and 6) actually distributed the transferee's outputs via their own facilities, and 4 more proffered advice on how to distribute products. 
Figure 2: Responses concerning areas and methods of mkh transfer

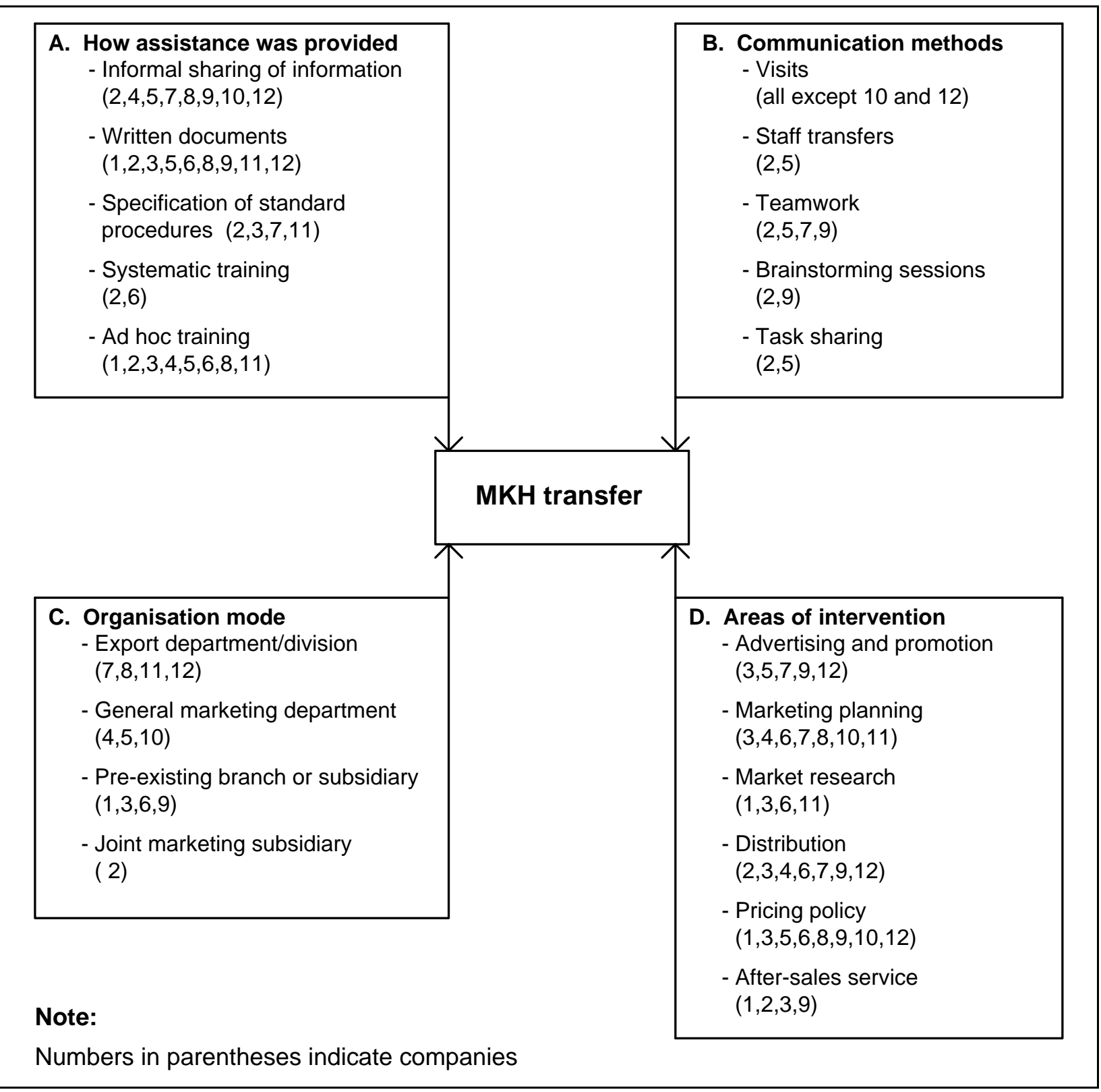

\section{Effectiveness of communications}

The communications methods adopted by Western companies when transmitting marketing know-how did not appear to correspond to those recommended by the academic literature on technology transfer. Most respondents stated (see Figure 2.A) that information was transmitted predominantly on an informal basis. Many companies transferred written documents regarding marketing techniques, e.g., sales manuals (firms $1,3,6,11$ ), standard distributor and other contracts used by the transferor for its general marketing operations $(2,3,5,7,11)$, and examples of mailshot and other promotional literature $(3,5,9,12)$. Some transferors made available to their CEE partners various systems and procedures employed within their own firms; such as customer database management systems (firms 2 and 11), credit control procedures (firm 2), market research templates (firm 11), and 
order processing systems (firms 2 and 11). It seemed however that a substantial amount of the documentation transferred related in some way or other to the Western companies' own in-house training programmes. Eight transferors stated that they offered training in marketing methods to their CEE partners, but only two companies described this as being rigorous and systematic (see Figure 2.A). The rest of the training offered was ad hoc in nature; variously described as 'showing the ropes' (firm 6), 'giving the tools to complete the job' (firm 3), 'giving an insight into what it's all about (firm 5), and similar perfunctory characterisations. Although all the respondents claimed that teamwork applied within their collaborative arrangements as a whole, only those in firms 2, 5, 7 and 9 mentioned this as a distinct feature of the transfer of marketing know-how. No respondent talked about brainstorming without a prompt; although when asked this specific question two (firms 2 and 9) said that brainstorming sessions had in fact occurred. Evidence of the deliberate sharing between personnel in transferor and recipient companies of tasks relating to the marketing function (as opposed to 'joint decision-making') emerged in just 2 cases (firms 2 and 5). Rather, transferees were usually presented with information, a set of operating procedures, documentation and so on, and then expected themselves to utilise the materials received. Where task sharing did occur it related to marketing planning, finding distributors, market research and the implementation of database systems.

\section{Transactions cost analysis}

Several respondents mentioned the existence of significant asset specificity in relation to CEE operations (see Figure 3.B). Following previous empirical research in this area (notably that of Anderson/ Coughlan 1987; Klein et al. 1990; McNaughton 1996) the presence of asset specificity was assessed via questions regarding whether the marketing of the end product required specialised facilities, substantial employee training, the development of specialist inside knowledge; whether it took a long time to get to know the customer and how difficult it would be for outsiders to learn how to market the product. Particular examples of asset specificity cited by interviewees included the need to develop specialised databases (firm 5), the effort involved in 'acquiring contacts and avenues for gathering intelligence' (firm 3), 'network development' (firm 7), and the dangers that would result if competitors obtained detailed information about the techniques and know-how used to market the item (firms 2, 5, 6, 7 and 11). The marketing director of company 2 pointed out that the staff involved in MKH transfer had to become familiar with business methods in the transferee's country, and this itself had a cost. He also commented upon the extra workloads falling on key marketing staff and the consequent increased complexity of their duties. 
Figure 3: Influences on intervention decisions

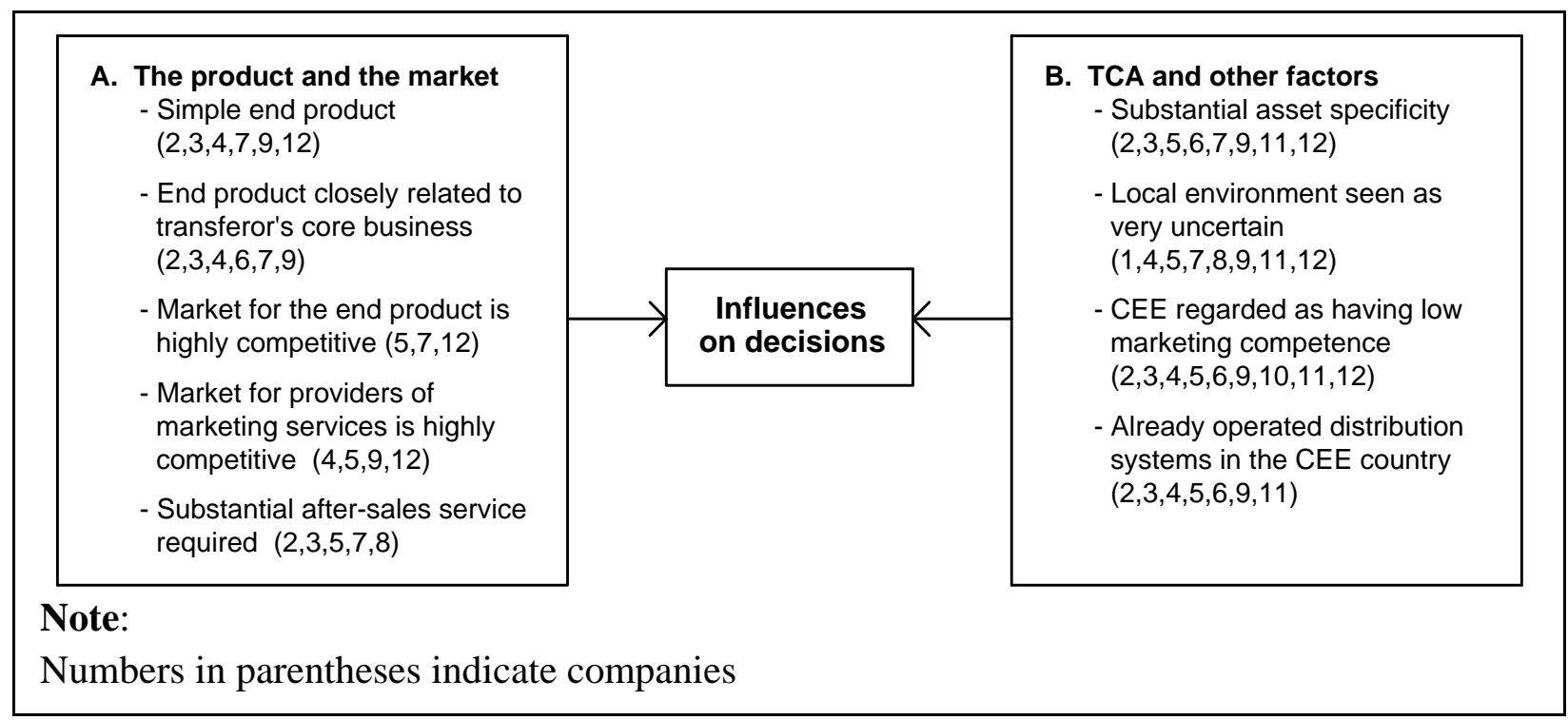

In line with pre-existing literature in the TCA area, respondents' perceptions of 'uncertainty' were tapped by asking whether they were 'frequently surprised' by the actions of competing businesses; outside distributors, retailers, agencies and other providers of marketing services; and by customer reactions to the product. Many respondents regarded CEE environments as highly uncertain (Figure 3.B), and this seemingly encouraged Western companies to want to intervene. As the international marketing director of Firm 9 commented, 'becoming involved (in the transferee's marketing) is vital to protect our interests in so erratic a market'. Uncertainty was perceived by this respondent as 'a state of flux in which you don't know who you can trust'. Apart from viewing CEE markets as uncertain, the great majority of respondents saw them as uncompetitive in relation both to the markets for end products and for the external provision of marketing services (Figure 3.A). Typical comments in these connections were that in many CEE countries, local distributors 'are few and far between and most of them are incompetent' (firm 2), that 'it is almost impossible to find out whether local market research firms, distributors, etc. are actually doing what they are supposed to do' (firm 3), and that 'if a local (marketing services) firm lets you down you haven't a hope of getting any compensation' (firm 8). The end product marketed in consequence of technology transfers was described as 'simple' (i.e. well-established or similar to local competing products) in 6 cases, and as being closely related to the transferor's core traditional or desired activities in 6 firms (Figure 3.A). Seven transferor companies already operated some form of distribution system within the transferee's country (see Figure 3.B).

\section{Relations with transferees}

Respondents generally held extremely low opinions of their CEE partners' marketing competencies (Figure 3.B), although this apparently did not worsen 
the quality of relationships between Western and CEE firms. All interviewees reported that inter-company relationships were (at least) satisfactory; 5 stated that transferees had eagerly taken up the help and advice the transferor had been able to provide (firms 2, 3, 7, 9, 10). No substantial conflicts or disagreements with CEE partners were mentioned regarding how exactly the end product should be marketed. When asked to justify their poor ratings of CEE enterprises' marketing abilities, respondents complained (inter alia) that 'the questions about marketing put forward by CEE executives were very basic and naive' (firm 4), that people in partner companies 'don't have a clue' where marketing is concerned (firm 3), and that there was 'no history of marketing' in CEE enterprises (firm 6). Several respondents commented on the differences between Western and CEE executives that existed vis à vis individual perceptions of what the term 'marketing' actually meant (firms 2, 3, 5, 6, 8, 11). Often 'marketing' was viewed by CEE managers as little more than selling and advertising (as reported by, for example, the respondents in firms 1, 3, 6 and 8), as opposed to an integrated package of activities that includes pricing policy, distribution, customer care, marketing planning, and so on.

Apart from the perceived lack of marketing acumen, no major problems relating to national cultural differences were reported that might hinder the effective transfer of marketing know-how to CEE firms, although a number of organisational barriers were mentioned. In particular, it was sometimes felt that decisions about marketing methods were delegated to too low a level within CEE partner enterprises (firms 2, 3, 5, 6), that insufficient managerial resources were devoted to marketing (firms $3,6,8,11$ ) and that too few of the transferee's employees were assigned to marketing activities (firms 2, 6, 8, 11). Hence, there appeared to be a 'managerial imbalance' in relation to approaches to the marketing function within Western and CEE firms. Two transferors (6 and 11) specifically mentioned problems within the organisational climates of recipient enterprises that might interfere with the practical implementation of the marketing know-how transferred. These complaints focused on apathy among the CEE partner's workforce, bureaucratic management structures, anticommercial philosophies held by certain individuals within partner enterprises, and poor management communication skills.

\section{Summary and discussion}

The picture that emerges from the present study is one wherein large Western companies are seemingly very keen to transmit MKH to CEE businesses, and the latter are anxious to receive the knowledge transferred. Respondents lacked confidence in their foreign partners' marketing competence, although this did not lead to bad intercompany relations. Two main groupings of companies within which similar characteristics and respondent attitudes could be identified emerge from the investigation, as follows. 
1. Large firms. Half of the six largest companies in the sample (firms 1 to 6) were involved in equity JVs, compared to just one in the remaining half dozen. Five out of six of these larger enterprises already operated branches or subsidiaries in transferees' countries and had extensive experience of Central and East Europe and of general international trade. Five of the companies had pre-existing distribution systems in the relevant CEE nation. All these large firms provided some form of marketing training to partners, and were more likely to furnish formal documentation.

2. Companies with CEE partners producing 'simple' end products. Firms in this category (see Figure 3.A) tended to have pre-existing distribution systems in their partners' countries, and respondents within them reported that substantial after-sales service was required. They contributed extensive assistance with foreign distribution (figure 2.D), and overall provided more help in other areas. Also they appeared to rely more on informal communications with CEE partners than did other companies. There was a considerable overlap between this group and companies reporting that transferees' end products had a close relation to their core businesses.

\section{Assessment of the initial propositions}

Two-thirds of respondents indicated the presence of significant asset specificity in relation to the marketing of end products (Figure 3.B). Three out of 4 interviewees in companies that intervened in the provision of after-sales service commented on the existence of asset specificity. Substantial overlaps were evident between companies with respondents who noted asset specificity and those intervening in transferees' distribution and advertising and promotion activities (Figure 2.D) Additionally, all companies that engaged in marketing teamwork and task sharing with CEE partners reported asset specificity, arguably because the presence of the latter encouraged the application of teamwork and task sharing methods. It was also the case that 5 out of 8 of the respondents who mentioned asset specificity also regarded local CEE markets as being highly uncertain. Examination of Figure 2.A reveals that these perceptions of asset specificity and uncertainty relate closely to (i) the use of written documents when furnishing assistance, and (ii) the provision of training to CEE firms. Uncertainty in local markets again appears to be positively associated with intervention vis à vis distribution and advertising and promotion. Overall, therefore, the results offer considerable support to the transactions cost hypothesis as outlined in Propositions 1 and 2. The majority of respondents viewed the markets both for end products and for service providers as fundamentally uncompetitive in CEE countries. Interestingly, firms with respondents who saw CEE markets as highly competitive (see Figure 3.A) were less likely to be involved in their foreign partners' marketing planning and market research activities than were the rest, lending tentative (albeit limited) support to 
Proposition 3. The fourth Proposition is also broadly supported, as previously discussed.

\section{Communications methods}

In general, respondent companies did not utilise the communication techniques recommended by the academic literature on technology transfer. Information transmission was essentially informal and ad hoc, typically involving occasional visits to transferee companies and the passing across of written documents used by transferors for their own domestic marketing. There was little evidence of staff transfers or task sharing teams made up of members from both enterprises, thus limiting the scope for converting brainware into groupware and meaningful documentware. Information flow was based more on shared informal understandings than on systematic procedures which spelt out in detail the activities, schedules and tasks that were required and which were likely to become permanently embedded in a transferee's knowledge base. Another problem was that whereas marketing was invariably seen as a senior management responsibility in Western companies, it was often regarded as a mundane operational matter in CEE firms. Another disturbing result was the obvious difference in Western and CEE executives' definitions of what the word 'marketing' actually meant. Such differences in interpretation could seriously damage the effectiveness of communications between partners concerning the implementation of marketing programmes. The specification of marketing objectives becomes difficult in such circumstances, and the criteria to be applied when managing various marketing functions may be unclear. Crucially interpretation differences could improperly influence transferees' expectations of the sorts of $\mathrm{MKH}$ that they require.

Although the results of the present study are highly provisional in nature, they do suggest that Western businesses wishing to transmit MKH to CEE nations should establish more formal and systematic procedures for communicating information than currently seem to apply. Also, greater consideration needs to be given to the issue of training the marketing employees of CEE firms. Some of these problems could be overcome, perhaps through Western companies getting together and collaboratively transferring MKH to groups of CEE enterprises. Alternatively it might be appropriate for external agencies (specialist training firms for instance) to take over Western companies' MKH transfer activities in their entirety. Further research is necessary in relation to this and a number of collateral matters. In particular, it would be useful to discover the factors which cause CEE firms to regard specific aspects of $\mathrm{MKH}$ as credible, reliable, and especially relevant to their needs. How in reality do CEE organisations learn about marketing? How permanent is the impact on CEE enterprises of the MKH information supplied by Western firms, and do they continue to apply the marketing methods they pick up from their Western partners to their own purely domestic operations in the longer term? 


\section{Acknowledgement}

The research assistance of Diane Hutchinson is gratefully acknowledged.

\section{References}

Anderson, E./ Coughlan, A. (1987): International Market Entry and Expansion via Independent or Integrated Channels of Distribution, in: Journal of Marketing, Vol. 51, pp. 71-82.

Anderson, J.C./ Narus, J.A. (1990): A Model of Distributor Firm and Manufacturer Firm Working Partnership, in: Journal of Marketing, Vol. 54, pp. 42-58.

Benito, G.R.G./ Welch, L.S. (1994): Foreign Market Servicing: Beyond Choice of Entry Mode, in: Journal of International Marketing, Vol. 22, pp. 7-27.

Bennett, R. (1994): Prospects for Business in the European Union. London.

Bennett, R. (1997): Foreign Marketing Control Decisions of Firms Engaged in West-East Technology Transfer: A Test of the Transactions Cost Hypothesis, In review.

Bonoma, T. (1985): Case Research in Marketing Opportunities: Problems and a Process, in: Journal of Marketing Research, Vol. 12, pp. 199-208.

Brown, S.L./ Eisenhardt, K.M. (1995): Product Development: Past Research, Present Findings, and Future Directions, in: Academy of Management Review, Vol. 20, pp. 343-378.

Bucklin, L.P./ Sengupta, S. (1993): Organising Successful Co-marketing Alliances, in: Journal of Marketing, Vol. 57, pp. 32-46.

CEC (Commission of the European Communities) (1995): Panorama of EU Industry, pp. 4153. Luxembourg: Office for Official Publications of the European Communities.

Churchill, G.A. (1991): Marketing Research: Methodological Foundations, 5th Edition, Orlando FL: Dryden Press.

Doz, Y.L. (1988): Technology Partnerships Between Larger and Smaller Firms: Some Critical Issues, in: International Studies of Management and Organisation, Vol. 17, pp. 31-57.

Eisenhardt, K.M. (1989): Building Theories from Case Study Research, in: Academy of Management Review, Vol. 14, pp. 532-550.

Ennew, C.T./ Filatotchev, I./ Wright, M./ Buck, T.W. (1993): Constraints on the Adoption of the Marketing Concept: The Case of the Former Soviet Union. In: European Journal of Marketing, Vol. 27, No. 11/12, pp. 21-34.

Gibson, D.V./ Williams, F./ Wohlert, K.L. (1990): The State of the Field: A Bibliographic View of Technology Transfer, in: Williams, F./ Gibson, D.V. (eds.): Technology Transfer: A Communications Perspective, London: Sage, pp.272-292.

Harrigan, K. (1983): Research Methodologies for Contingency Approaches to Business Strategy, in: Academy of Management Review, Vol. 8, pp. 398-405.

Hooley, G./ Cox, T./ Shipley, D./ Beracs, J./ Kolos, K./ Fonfara, K./ Marinov, M. (1996): Marketing Planning in Central and Eastern Europe, in: Journal of Marketing Management, Vol. 12, pp. 69-82. 
Jain, R.K./ Triandis, H.C. (1990): Management of Research and Development Organisations: Managing the Unmanageable, New York: Wiley and Sons.

Kerlinger, F.N. (1964): Foundations of Behavioural Research, London: Holt, Rinehart and Winston.

Kerssens-Van Drongelen, I.C./ Weerd-Nederhof, P.C./ Fisscher, O.A.M. (1996): Describing the Issues of Knowledge Management in R\&D: Towards a Communication and Knowledge Tool, in: R\&D Management, Vol. 26, pp. 213-230.

Klein, S./ Frazier, G.L./ Roth, V.J. (1990): A Transaction Cost Analysis Model of Channel Integration in International Markets, in: Journal of Marketing Research, Vol. 27, pp. 196-208.

Lascu, D.N./ Manrai, L.A./ Manrai, A.K. (1993): Marketing in Romania: The Challenges of the Transition from a Centrally-Planned Economy to a Consumer-Oriented Economy, in: European Journal of Marketing, Vol. 27, No. 11/12, pp. 102-124

McNaughton, R.B. (1996): Foreign Market Channel Integration Decisions of Canadian Computer Software Firms, in: International Business Review, Vol. 5, pp. 23-52.

Miles, M.B./ Huberman, A.M. (1994): Qualitative Data Analysis: An Expanded Sourcebook, 2nd Edition, London: Sage.

Moenaert, R.K./ Deschoolmeester, D./ De Meyer, A./ Souder, W.E. (1992): Information Styles of Marketing and R\&D Personnel During Technological Product Innovation Projects, in: R\&D Management, Vol. 22, pp. 1-23.

Phillips, L.W. (1981): Assessing Measurement Error in Key Informant Reports: A Methodological Note on Organisational Analysis in Marketing, in: Journal of Marketing Research, Vol. 28, pp. 395-415.

Robson, S./ Foster, A. (1989): Qualitative Research in Action, London: Edward Arnold.

Roos, J./ Veie, E./ Welch, L.S. (1992): A Case Study of Equipment Purchasing in Czechoslovakia, in: Industrial Marketing Management, Vol. 21, pp. 257-263.

Seidler, J. (1974): On Using Informants: A Technique for Collecting Quantitative Data and Controlling Measurement Error in Organisation Analysis, in: American Sociological Review, Vol. 39, pp. 816-831.

Stake, R. (1995): The Art of Case Study Research, Thousand Oaks, CA: Sage.

Tremblay, M.A. (1982): The Key Informant Technique: A Non-Ethnographic Application, in: Burgess, R. (ed.): Field Research: A Sourcebook and Field Manual, London: Allen and Unwin.

Welch, L.S. (1996): Information Behaviour and Internationalisation, in: International Journal of Technology Management, Vol. 11, No. 1/2, pp. 179-191.

Williamson, O. (1985): The Economic Institutions of Capitalism, New York: The Free Press.

Yin, R. (1994): Case Study Research: Design and Methods, London: Sage.

Zeleny, M./ Cornet, R.J./ Stoner, J.A.F. (1990): Moving from the Age of Specialisation to the Era of Integration, in: Human Systems Management, Vol. 9, pp. 153-157. 